\title{
KINERJA RANTAI PASOK KEDELAI DI KABUPATEN GROBOGAN
}

\section{THE PERFORMANCE OF SOYBEAN SUPPLY CHAIN AT GROBOGAN DISTRICT}

\author{
Bubun $^{*}$,, Sukardi ${ }^{* *}$, dan Ono Suparno ${ }^{* *}$ \\ *) Direktorat Jenderal Bina Tanaman Pangan, Kementerian Pertanian, Republik Indonesia \\ Jl. AUP No. 3 Pasar Minggu, Jakarta Selatan 12520 \\ ${ }^{* *}$ Departemen Teknologi Industri Pertanian, Fakultas Teknologi Pertanian, Institut Pertanian Bogor \\ Gedung Fateta Lantai 2, Kampus IPB Dramaga 16680
}

\begin{abstract}
The objectives of this study were to illustrate the structure of the soybean supply chain, to identify the performance of the soybean supply chain, and to recommend improvements in the form of managerial implications. This research used descriptive analysis method, and the analyzer used in this research was Supply Chain Operation References (SCOR). This study used primary data and secondary data. The primary data were obtained from direct observations, Focus Group Discussion (FGD), in depth interviews, and questionnaire whereas the secondary data were collected from literature study, farmer group data and agricultural statistical data from the Agriculture Department and Ministry of Agriculture. Based on the analysis of the supply chain structure, it was illustrated that there are two major parts of the supply chain structure, i.e. the short structure in which the breeder group acts as the main distributor, and the long supply chain structure in which the distribution pattern starts from the agent and dealer prior to reaching consumers. In general, the performance of the soybean supply chain in Grobogan Regency is reasonably good as it can be seen from the orders delivered to the customers and the perfect and in time order fulfillment as well as the suitability of the product with the increasing qualification standard. The order fulfillment cycle also can be adjusted with stock availability, and the supply chain flexibility can still be optimized when there is a sudden order, and supply chain costs can be covered from the sales of soybeans.
\end{abstract}

Keywords: soybeans (Anguilla spp.), SCOR, supply chain, Grobogan District

\begin{abstract}
Abstrak: Tujuan dari penelitian ini adalah untuk menggambarkan struktur rantai pasok kedelai, mengetahui kinerja rantai pasok kedelai, dan merekomendasikan perbaikan berupa implikasi manajerial. Penelitian ini menggunakan metode analisis deskriptif. Alat analisis yang digunakan dalam penelitian ini adalah Supply Chain Operation References (SCOR). Penelitian ini menggunakan data primer dan data sekunder. Berdasarkan hasil analisis struktur rantai pasok digambarkan bahwa terdapat dua bagian besar struktur rantai pasok, yaitu struktur pendek berupa di mana kelompok tani penangkar benih berperan sebagai distributor utama, dan struktur rantai pasok panjang di mana pola distribusinya melalui agen dan bandar terlebih dahulu sebelum sampai ke konsumen. Secara umum kinerja rantai pasok kedelai di Kabupaten Grobogan dikatakan cukup baik, hal ini dapat dilihat dari pengiriman pesanan ke pelanggan dan pemenuhan pesanan yang sempurna, kesesuaian produk dengan standar kualifikasi yang terus meningkat, waktu tunggu pemenuhan pesanan yang tidak terlalu lama, siklus pemenuhan pesanan juga dapat disesuaikan dengan ketersediaan stok, fleksibiitas rantai pasokan masih dapat doptimalkan bila terdapat pesanan mendadak dan biaya rantai pasok yang dapat tertutupi dari nilai penjualan kedelai.
\end{abstract}

Kata kunci: kedelai (Anguilla spp), SCOR, rantai pasok, Kabupaten Grobogan

\footnotetext{
${ }^{1}$ Corresponding author:

Email: bubun.hasbulloh@yahoo.com
} 


\section{PENDAHULUAN}

Kedelai adalah salah satu komoditas tanaman pangan utama setelah padi dan jagung yang sangat diperlukan untuk meningkatkan gizi masyarakat karena memiliki kandungan potein nabati yang tinggi dan kandungan kolesterol yang rendah. Kedelai merupakan bahan pangan yang mengandung protein nabati yang sangat tinggi nilai gizinya, mengandung zat antioksidan yang tinggi sehingga sangat bermanfaat bagi kesehatan (Isnowati, 2014). Konsumsi protein yang bersumber dari kedelai adalah yang terbesar dari pangan nabati serta merupakan pilihan kedua setelah ikan dari kelompok protein hewani (Fizzanty dan Aminullah, 2010). Kompleksitas penyediaan pangan kedelai muncul ketika konsumsi sudah menjadi tradisi dan membentuk pola makan masyarakat.

Kebutuhan kedelai dari tahun ke tahun terus meningkat seiring dengan bertambahnya jumlah penduduk serta berkembangnya industri pangan dan industri pakan ternak yang berbahan baku kedelai. Dalam proyeksi konsumsi kedelai oleh Simatupang et al. (2005) total kebutuhan terus mengalami peningkatan dari 2,35 juta ton pada tahun 2009 menjadi 2,71 juta ton pada tahun 2015 dan 3,35 juta ton pada tahun 2025. Ketergantungan pada pasar impor saat ini adalah keniscayaan, rata-rata kebutuhan kedelai setiap tahunnya sebanyak $\pm 2,2$ juta ton, akan tetapi kemampuan produksi dalam negeri saat ini baru mampu memenuhi sebanyak $43,95 \%$ terhadap kebutuhan, dan sisanya sebesar 56,05\% dipenuhi dari impor (Kementan, 2015). Impor menyebabkan hilangnya devisa dan meningkatkan ketergantungan jangka panjang yang akan berpengaruh pada sistem ketahanan pangan nasional. Makin tinggi jumlah impor maka harga kedelai di tingkat petani semakin turun, sebaliknya semakin rendah harga kedelai impor maka harga kedelai di tingkat petani juga turun (Zakiah, 2011). Selama kurun waktu tahun 2011-2015, data impor menunjukkan angka yang sangat besar sebagaimana pada Tabel 1.

Saat ini permintaan kedelai yang tinggi terutama dipicu oleh kebutuhan konsumsi. Pada kenyataannya permintaan kedelai terus meningkat seiring dengan meningkatnya jumlah penduduk. Hal ini dipicu oleh kebutuhan pemenuhan gizi masyarakat yang berasal dari protein nabati kedelai yang terjangkau tersebut telah membentuk pola makan masyarakat. Kebutuhan penenuhan gizi yang berasal dari kedelai terus mengalami peningkatan dan mendorong berkembangnya usaha pengolahan pangan dan benih kedelai. Untuk menyediakan kedelai, perlu digiatkan produksi kedelai lokal, sebab ketergantungan pada impor akan semakin rawan dan harga kedelai impor juga akan semakin mahal. Sistem penyediaan kedelai lokal dengan berbagai kendalanya perlu ditelaah lebih lanjut terutama dalam hal sistem tata niaga. Mengacu pada apa yang disampaikan oleh Chopra dan Meindl (2007) bahwa strategi ideal dalam manajemen rantai pasok adalah menekankan adanya efisiensi dan mengelola kemapuan dalam ketepatan merespon permintaan konsumen yang diwujudkan dalam aplikasi kebijakan perusahaan dalam menangani enam faktor pendorong kinerja rantai pasokan, yaitu fasilitas, persediaan, transportasi, informasi, sumber daya dan harga. Permasalahan efisiensi dan responsibilitas tersebut harus dicari penyelesaiannya dan dirumuskan menjadi sebuah rekomendasi manajerial untuk perbaikan kinerja sebuah rantai pasok.

Keberlangsungan proses produksi kedelai di Kabupaten Grobogan berjalan dengan baik dan simultan. Petani di Kabupaten Grobogan telah terbiasa melakukan budidaya kedelai hingga dua kali tanam dalam setahun dengan tanaman padi sebagai tanaman sela. Sebagian besar kebutuhan benih kedelai nasional juga dipasok oleh bandar dan petani penangkar di Kabupaten Grobogan. Sejauh ini, kendala yang dihadapi petani kedelai di Kabupaten Grobogan adalah; (1) penggunaan benih bermutu masih sangat rendah, (2) risiko budidaya kedelai cukup besar terutama adanya serangan hama/penyakit, (3) penanganan pascapanen terutama pada tahap pengeringan kurang memadai dan (4) jaminan harga kedelai dari pemerintah belum berjalan karena pada pada musim panen raya harga kedelai impor menjadi lebih murah dibanding kedelai lokal. Permasalahan tersebut merupakan permasalahan umum yang dihadapi dalam upaya pengembangan kedelai di Indonesia.

Tabel 1. Ketergantungan impor kedelai tahun 20112015

\begin{tabular}{ccc}
\hline \multirow{2}{*}{ Tahun } & \multicolumn{2}{c}{ Total Impor } \\
\cline { 2 - 3 } & (Ton) & \% kenaikan \\
\hline 2011 & 2.087 .986 & - \\
2012 & 2.104 .912 & 0,81 \\
2013 & 1.785 .327 & $-15,18$ \\
2014 & 1.964 .081 & 10,01 \\
2015 & 2.256 .932 & 14,91 \\
$\left.2016^{*}\right)$ & 1.311 .611 & $-41,89$ \\
Rata-rata & 2.039 .848 & $-2,64$ \\
\hline
\end{tabular}


Namun, dengan berbagai permasalahan tersebut, Kabupaten Grobogan mampu menjadi daerah sentra produksi kedelai. Di samping itu, kebutuhan benih nasional sebagian besar dipasok dari Kabupaten Grobogan. Sebagai salah satu sentra kedelai di Provinsi Jawa Tengah, Kabupaten Grobogan memiliki stakeholders yang cukup lengkap bila dilihat dari aspek tata niaga. Kondisi rantai pasok kedelai di Kabupaten Grobogan saat ini termasuk yang paling baik di antara beberapa wilayah sentra produksi kedelai di Indonesia. Fenomena tersebut merupakan keunikan Kabupaten Grobogan dibanding dengan sentra kedelai lain di Indonesia. Bila diukur secara ilmiah, tentu terdapat indikator yang dapat dijadikan acuan bagi wilayah sentra kedelai lain agar tata niaga kedelainya dapat berjalan dengan baik.

Dalam rangka mengetahui pola rantai pasok kedelai yang paling baik, upaya penelaahan lebih lanjut mengenai tata niaga kedelai di Kabupaten Grobogan dipandang perlu dilakukan. Bagaimana struktur dan pola manajemen rantai pasok serta sejauh mana kinerja rantai pasokan kedelai yang berlangsung di Kabupaten Grobogan sebagai daerah sentra kedelai perlu dianalisis sehingga pola manajemen rantai pasok tersebut diharapkan dapat dijadikan contoh dan referensi dalam memperbaiki permasalahan tata niaga kedelai di beberapa sentra kedelai di Indonesia. Tujuan penelitian ini adalah mengidentifikasi struktur rantai pasok kedelai di Kabupaten Grobogan, menganalisis kinerja rantai pasok kedelai di Kabupaten Grobogan.

\section{METODE PENELITIAN}

Jenis data yang digunakan adalah data primer dan data sekunder. Data primer meliputi aspek produksi dan distribusi kedelai yang diperoleh melalui wawancara mendalam (in depth interview) dan pengisian kuesioner oleh responden yaitu petani kedelai, petani penangkar benih, koperasi petani, bandar dan konsumen akhir baik unit pengolahan hasil maupun rumah tangga. Data sekunder berupa data-data yang relevan dari Dinas Pertanian Kabupaten Grobogan, Kementerian Pertanian, BPS dan asosiasi pengusaha kedelai.

Pengukuran kinerja rantai pasok kedelai dalam penelitian ini akan menggunakan alat ukur berupa pertanyaan terbuka dan tertutup, di mana yang dimaksud dengan pertanyaan terbuka adalah subjek dapat mengisi alat ukur selain pilihan jawaban yang disediakan, sedangkan pertanyaan tertutup adalah pertanyaan dengan pilihan. Data yang akan dianalisis nantinya adalah data yang dikumpulkan melalui survei kuesioner (data primer) serta data sekunder berupa informasi yang disampaikan oleh narasumber dalam hal ini petugas dinas pertanian Kabupaten Grobogan selaku pelasana teknis kebijakan di lapangan dan pakar yang relevan dengan topik penelitian.

Pengambilan sampel penelitian ini menggunakan teknik non probability sampling, yaitu teknik pengambilan sampel yang tidak memberikan kesempatan kepada setiap anggota populasi untuk dijadikan anggota sampel, karena populasi yang diteliti jumlah dan identitas anggota populasi tidak diketahui. Adapun metode pengambilan sampel pada penelitian ini dilakukan dengan pengambilan sampel secara convenience sampling.

Teknik penetapan responden menggunakan purposive sampling, di mana pengambilan sampel dilakukan hanya atas dasar pertimbangan penelitinya saja yang menganggap unsur-unsur yang dikehendaki telah ada dalam anggota sampel yang diambil (Nasution, 2003). Jumlah responden yang digunakan sebanyak sepuluh responden internal (kelompok tani) dan tiga responden eksternal (satu akademisi dan dua dari Dinas Pertanian Kabupaten Grobogan).

Metode yang digunakan dalam penelitian ini adalah analisis deskriptif dengan pendekatan alat analisis menggunakan Supply Chain Operation References (SCOR). SCOR merupakan model pengukuran kinerja rantai pasokan yang baik, karena SCOR membagi proses-proses rantai pasokan menjadi lima proses inti, yaitu plan, source, make, deliver dan return yang merepresentasikan seluruh aktivitas rantai pasokan dari hulu ke hilir secara detail sehingga dapat mendefinisikan dan mengkategorikan proses-proses yang membangun metrik-metrik atau indikator pengukuran yang diperlukan (Setiawan et al. 2010). Model penilaian dalam SCOR dinyatakan dalam ukuran kuantitatif dengan metrik-metrik penilaian yang dinyatakan dalam beberapa level tingkatan meliputi level 1 (Tabel 2). Pada penelitian ini setiap indikator kinerja akan diuraikan berdasarkan metrik-metrik kinerja. Deskripsi dan perhitungan metrik kinerja disajikan pada Tabel 3. Kerangka penelitian selengkapnya dapat dilihat pada Gambar 1. 
Tabel 2. Kartu bobot penilaian model SCOR Supply Chain Council Version 10.0

\begin{tabular}{lll}
\hline Sumber faktor & Atribut kinerja & Metrik SCOR level 1 \\
\hline Eksternal & Tingkat keandalan rantai pasok (realibility) & Pemenuhan pesanan \\
& & Kinerja pengiriman \\
& Kemampuan respon rantai pasok (responsiveness) & Kesesuaian dengan standar mutu \\
& Waktu siklus pemenuhan pesanan \\
& Tingkat kecerdasan rantai pasok (agility) & Lead time pemenuhan pesanan \\
& & Fleksibilitas rantai pasok \\
Internal & Biaya rantai pasok & Daya adaptasi rantai pasok \\
& Manajemen aset rantai pasok & Biaya total manajemen rantai pasok \\
& & Waktu siklus kas \\
& & Laba atas aset tetap rantai pasok \\
& & Laba atas modal kerja \\
\hline
\end{tabular}

Tabel 3. Perhitungan metrik-metrik kinerja untuk model SCOR

\begin{tabular}{|c|c|c|c|}
\hline $\begin{array}{l}\text { Atribut } \\
\text { kinerja }\end{array}$ & Metrik kinerja & Satuan & Cara perhitungan \\
\hline \multirow[t]{3}{*}{ Reliabilitas } & $\begin{array}{l}\text { Pemenuhan pesanan adalah presentase jumlah } \\
\text { permintaan, dipenuhi tanpa menunggu, diukur tiap } \\
\text { jenis produk }\end{array}$ & Persen & $\begin{array}{l}\text { Permintaan konsumen yang dipenuhi } \\
\text { dalam waktu \& jumlah yang sesuai \& } \\
\text { full/total pesanan }\end{array}$ \\
\hline & $\begin{array}{l}\text { Kinerja pengiriman adalah presentase pengiriman } \\
\text { tepat waktu yang sesuai dengan tanggal pemesanan } \\
\text { konsumen dan atau tanggal yang diinginkan } \\
\text { konsumen }\end{array}$ & Persen & $\begin{array}{l}\text { Pengiriman pesanan yang tepat waktu/ } \\
\text { total pesanan konsumen }\end{array}$ \\
\hline & Kesesuaian dengan standar atau mutu & Persen & $\begin{array}{l}\text { Pengiriman yang sesuai/jumlah } \\
\text { pengiriman }\end{array}$ \\
\hline \multirow{2}{*}{$\begin{array}{l}\text { Kecepatan } \\
\text { tanggapan }\end{array}$} & Siklus pemenuhan pesanan & Hari & Siklus (Source+make+delivery) \\
\hline & $\begin{array}{l}\text { Lead time pemenuhan pesanan adalah menerangkan } \\
\text { waktu yang dibutuhkan oleh perusahaan untuk } \\
\text { memenuhi permintaan konsumen mulai dari } \\
\text { pemasok hingga ke tangan konsumen }\end{array}$ & Hari & $\begin{array}{l}\text { Jumlah hari sejak produk diproduksi/ } \\
\text { diproses hingga dikirim sampai ke } \\
\text { tangan konsumen }\end{array}$ \\
\hline Fleksibilitas & $\begin{array}{l}\text { Fleksibilitas rantai pasok adalah waktu yang } \\
\text { diperlukan untuk merespon rantai pasokan apabila } \\
\text { ada pesanan yang tak terduga baik peningkatan } \\
\text { maupun penurunan pesanan tanpa terkena biaya } \\
\text { pinalti }\end{array}$ & Hari & $\begin{array}{l}\text { Jumlah dari siklus mencari } \\
\text { barang+siklus membuat+siklus } \\
\text { mengirim+leadtime }\end{array}$ \\
\hline Biaya & $\begin{array}{l}\text { Biaya total manajemen rantai pasokan adalah total } \\
\text { biaya yang dikeluarkan oleh perusahaan dalam } \\
\text { melakukan material handling mulai dari pemasok } \\
\text { hingga ke konsumen }\end{array}$ & Rupiah & $\begin{array}{l}\text { Jumlah biaya dari (perencanaan }+ \\
\text { pengadaan }+ \text { pembuatan }+ \text { pengiriman }+ \\
\text { pengembalian) }\end{array}$ \\
\hline \multirow[t]{2}{*}{ Aset } & $\begin{array}{l}\text { Cash to cash cycle time adalah perputaran uang } \\
\text { perusahaan mulai dari pembayaran bahan baku } \\
\text { ke pemasok, hingga pembayaran atau pelunasan } \\
\text { produk ke konsumen }\end{array}$ & Hari & $\begin{array}{l}\text { Rata-rata persediaan/hari+rata-rata } \\
\text { konsumen membayar (hari)-rata-rata } \\
\text { perusahaan membayar ke pemasok } \\
\text { (hari) }\end{array}$ \\
\hline & Persediaan harian untuk pemasok & Hari & $\begin{array}{l}\text { Waktu yang dibutuhkan sampai barang } \\
\text { dikirim ke pelanggan }\end{array}$ \\
\hline
\end{tabular}




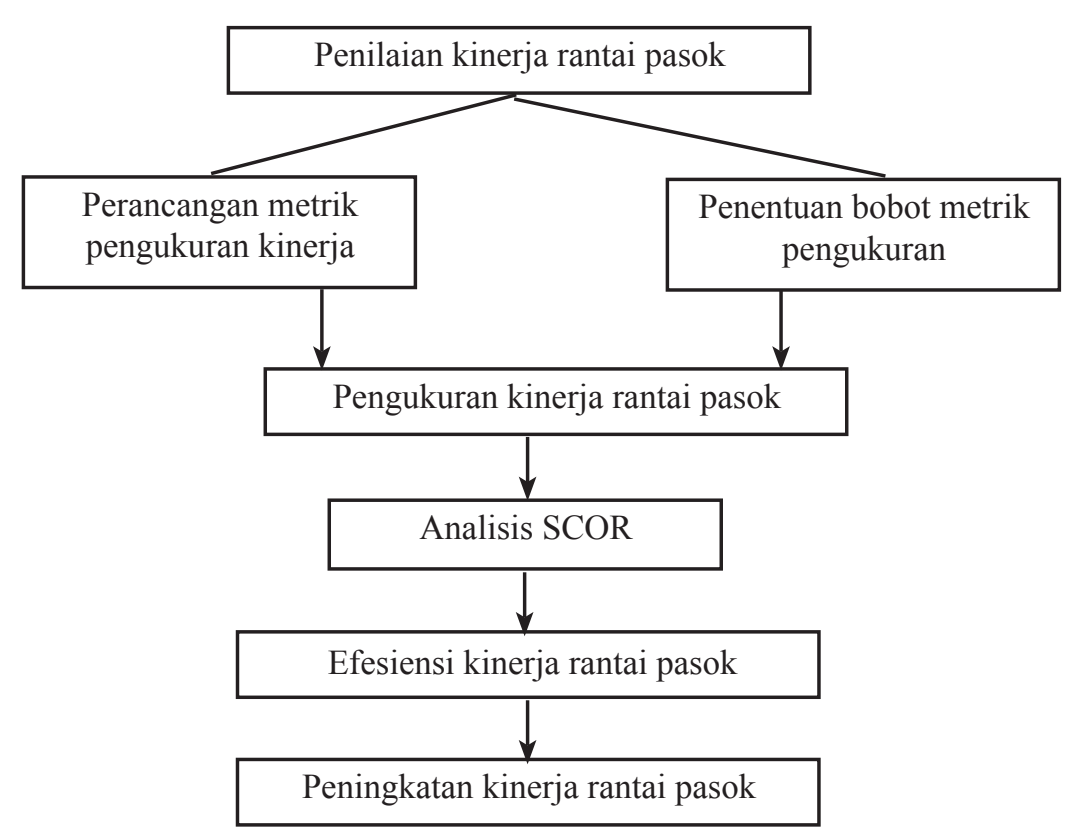

Gambar 1. Kerangka pemikiran penelitian

\section{HASIL}

\section{Keadaan Umum Kabupaten Grobogan}

Komoditi pertanian yang banyak di usahakan oleh petani di Kabupaten Grobogan adalah komoditi tanaman pangan, terutama padi dan kedelai. Kondisi topografi Kabupaten Grobogan yang landai dikelilingi pegunungan kapur dan perbukitan yang membujur dari barat ke timur telah mendorong petani untuk menanam kedelai. Produksi kedelai Kabupaten Grobogan mencapai rata-rata 2-3,5 ton/ha menggunakan varietas Grobogan yang memiliki kualitas terbaik dengan kadar protein mencapai $60 \%$. Benih jenis ini diakui mempunyai banyak keunggulan yakni, berumur pendek, tidak menghalangi pola tanam, produktivitas tinggi dan kaya kandungan protein (Iriani dan Handoyo, 2011).

\section{Struktur Rantai Pasok Kedelai}

Struktur rantai pasok menjelaskan mengenai pihak yang terlibat dan perannya serta aliran informasi, produk dan uang pada rantai pasok (Astuti et al. 2010). Menurut Marimin dan Nurul (2010) petani dapat langsung menjual hasil pertaniannya langsung ke pasar selaku retail sehingga telah memutuskan rantai pelaku tengkulak, manufaktur dan distributor. Berikut merupakan penjabaran struktur rantai pasok kedelai di Kabupaten Grobogan:
1) Pemasok; terdiri dari pemasok benih kedelai, terdiri dari bandar dan kelompok petani penangkar. Proses penyediaan benih kedelai melalui proses dan tahapan yang berurut mulai dari sortasi kedelai panen, tahapan pascapanen dan sertifikasi benih.

2) Petani Pembudidaya; merupakan petani yang bermitra dengan perusahaan atau bandar. Sebagian petani menjual kedelai ke bandar dan sebagian lain menjual ke kelompok tani penangkar benih, tergantung kesepakatan keduanya.

3) Distribution Channel (DC); merupakan saluran distribusi penjualan kedelai dari petani. DC pada rantai pasok kedelai di Kabupaten Grobogan bisa terdiri dari agen dan bandar.

4) Konsumen, yaitu konsumen rumah tangga yang menggunakan kedelai sebagai bahan panganan untuk dikonsumsi di rumah, serta konsumen berupa unit pengolahan yang memerlukan kedelai sebagai bahan baku untuk membuat produk olahan untuk dikonsumsi masyarakat.

Masing-masing anggota struktur rantai pasok melakukan aktivitas dengan proses-proses yang saling terkait dalam sistem pemasaran kedelai. Tingkatan pelaku pada rantai pasok kedelai tersebut disajikan pada Tabel 4. 
Tabel 4. Aktivitas pelaku rantai pasok kedelai

\begin{tabular}{llll}
\hline Tingkatan & \multicolumn{1}{c}{ Pelaku } & \multicolumn{1}{c}{ Proses } & \multicolumn{1}{c}{ Aktivitas } \\
\hline Produsen & Petani & - Pembelian & Melakukan pembelian benih dan sarana produksi dari pemasok \\
& & - Budi daya & Melakukan budidaya tanaman kedelai \\
Pengumpul & Agen & - Penjualan & Melakukan penjualan kedelai ke perusahaan atau bandar \\
& & - Penjualan & Melakukan pembelian kedelai dari petani, dan pembelian benih dari bandar \\
Produsen & Petani & - Pembelian & Melakukan pembelian kedelai dari petani dan agen \\
benih & penangkar & - Sortasi & Melakukan sortasi dan grading kedelai \\
& dan bandar & - Produksi benih & Melakukan proses produksi benih dan mengajukan sertifikasi benih \\
& & - Penampungan & Menampung benih kedelai untuk dijual \\
& & - Penjualan & Melakukan penjualan benih kepada petani dan agen \\
Konsumen & Pasar & - Pembelian & Melakukan pembelian kacang kedelai dari agen atau bandar \\
& tradisional & - Penyimpanan & Melakukan penyimpanan bila kacang kedelai belum terjual atau sebagai \\
& dan UPH & & bahan baku proses pengolahan kedelai \\
& & - Penjualan & Melakukan penjualan kedelai kepada konsumen akhir \\
\hline
\end{tabular}

\section{Manajemen Rantai Pasok}

Pada tingkatan agroindustri, manajemen rantai pasok memberikan perhatian pada pasokan, persediaan dan juga transportasi untuk pendistribusiannya (Vorst, 2004). Manajemen rantai pasok pada produk pertanian seperti kedelai selain sangat sensitif terhadap kualitas dan mutu, juga sangat sensitif terhadap jumlah pasokan, hal tersebut dikarenakan produk pertanian sangat bergantung pada kondisi alam. Manajemen rantai pasok bertujuan untuk membuat seluruh sistem menjadi efisien dan efektif, meminimalisasi biaya dari transportasi dan distribusi sampai inventori bahan baku, bahan alam proses serta barang jadi (Marimin dan Nurul, 2010). Dalam penerapan manajemen rantai pasok terkandung di dalamnya penerapan budi daya tanaman yang baik, penanganan pascapanen yang baik, distribusi yang baik serta cara pemasaran yang baik (Rachmat et al. 2012). Menurut Marimin et al. (2010) dalam SCOR proses rantai pasokan tersebut didefinisikan ke dalam lima proses yang terintegrasi, yaitu perencananaan (plan) pengadaan (source), produksi (make), distribusi (deliver) dan pengembalian (return).

1. Perencanaan (plan), proses menyeimbangkan permintaan dan pasokan untuk menentukan tindakan terbaik dalam memenuhi kebutuhan pengadaan, produksi dan pengiriman. Pemasok bahan baku benih kedelai yaitu penangkar dan bandar, dipesan melalui komunikasi langsung dengan petani.

2. Pengadaan (source), proses pengadaan barang maupun jasa untuk memenuhi permintaan. Proses yang dicakup termasuk penjadwalan pengiriman dari pemasok, menerima, mengecek, memberikan otorisasi pembayaran barang yang dikirim pemasok, memilih pemasok, dan evaluasi kinerja pemasok.

3. Pembuatan (make), proses untuk mentransformasi bahan baku menjadi produk yang diinginkan pelanggan, mencakup penjadwalan produksi melakukan pengetesan kualitas, mengelola barang setengah jadi dan memelihara faktor produksi.

4. Pengantaran (delivery), proses untuk memenuhi permintaan terhadap barang maupun jasa, biasanya meliputi order management, transportasi dan distribusi. Alat transportasi untuk pendistribusian kedelai yatu mobil bak dan mobil truk.

5. Pengembalian (return), proses pengembalian atau menerima pengembalian produk karena berbagai alasan. Kegiatan yang terlibat antara lain identifikasi kondisi kedelai dan mengembalikan kedelai bila ada yang tidak sesuai dengan mutu.

\section{Pemilihan Mitra}

Kemitraan dinilai sebagai salah satu pendekatan yang paling prospektif dapat mengangkat ekonomi petani (Martius, 2008). Pemilihan mitra dalam sistem agribisnis didasarkan pada rekomendasi pemerintah (Saptana dan Ashari, 2007). Sebagian petani kedelai di Kabupaten Grobogan lebih menyukai kedelainya dibeli oleh agen atau bandar. Tetapi ada pula petani yang merasa nyaman menjual hasil panen kedelai mereka ke 
petani penangkar karena harga jual yang lebih tinggi dan semua hasil panen dibeli tanpa sortasi. Ruswanti (2011) menyatakan bahwa kemitraan dibangun dengan menekankan pentingnya hubungan baik jangka panjang dengan konsumen, dan memperpanjang daur hidup pelanggan. Hubungan kedekatan antara petani dengan bandar maupun dengan penangkar benih menjadi modal yang kuat dalam keterjaminan pemasaran kedelai.

\section{Kesepakatan Kontraktual}

Kesepakatan kontraktual merupakan kontrak yang berisi segala hal yang telah disepakati antar pihak yang bekerja sama baik secara formal maupun informal yang berfungsi untuk memberi batasan-batasan dan tanggungjawab yang harus dilakukan oleh masingmasing pihak. Kesepakatan yang dibuat antara petani terhadap bandar dan penangkar berupa kesepakatan lisan, bukan kontrak formal. Perjanjian atau kesepakatan dilakukan secara formal dan tertulis bila yang membeli adalah pihak pemerintah dalam rangka penyediaan dan penyaluran benih kedelai. Sistem transaksi antara petani mitra dan pembeli adalah sistem dengan cash and carry.

\section{Dukungan Kebijakan}

Pengembangan komoditas kedelai di Kabupaten Grobogan didukung oleh kebijakan himbauan pola tanam padi padi palawija (secara khusus kedelai). Petani mengharapkan adanya kebijakan yang dilakukan pemerintah terkait dengan stabilitas harga dan permodalan. Kebijakan insentif harga kedelai yang rendah bagi petani menyebabkan tidak adanya rangsangan yang kuat bagi petani untuk mengembangkan kedelai (Nuhung, 2013). Menurut Atman (2009) dalam rangka pengembangan agribisnis kedelai diperlukan sebuah gerakan yang dikomandoi oleh Pemerintah Daerah dengan tetap mengacu pada kebijakan pengembangan kedelai secara nasional. Kegiatan penyuluhan dilakukan dengan baik oleh Dinas Pertanian Tanaman Pangan dan Hortikultura Kabupaten Grobogan dalam rangka mensosialisasikan kegiatan budidaya dan pascapanen kedelai yang baik dan benar.

\section{Kolaborasi Rantai Pasok}

Kolaborasi rantai pasok dapat dilihat dari adanya information sharing secara sukarela dan timbal balik antar setiap anggota rantai pasok. Aliran informasi merupakan proses komunikasi yang bergerak baik dari hulu ke hilir maupun sebaliknya hilir ke hulu (Isnia, et al. 2017). Menurut Sundram et al. (2011), tingkat berbagi informasi dengan mitra merupakan elemen penting dari rantai pasokan yang mencerminkan kuantitas dari informasi yang dibagikan. Informasi berasal dari konsumen yang disampaikan kepada pelaku rantai pasok lain dan sebaliknya.

\section{Proses Bisnis Rantai Pasok}

Hubungan proses bisnis rantai pasokan sangat ditentukan oleh kekuatan posisi tawar (bargaining position) antara anggota rantai pasok melalui proses penentuan harga jual produk. Kekuatan tawar menawar yang dimiliki petani lebih rendah dari bandar maupun agen. Hal ini dilihat saat kondisi kedelai mengalami kelangkaan, harga kedelai menjadi tinggi, begitupun sebaliknya saat terjadi panen raya kedelai maka harga kedelai akan turun, dalam kondisi seperti ini harga kedelai menjadi sangat rendah. Hubungan keterkaitan antar anggota struktur rantai pasok serta pengaruh yang ada dapat dilihat melalui hubungan proses bisnis yang telah terjalin.

\section{Pola Distribusi}

Pola aliran distribusi kedelai di Kabupaten Grobogan pada dasarnya memiliki pola yang berbeda, perbedaan tersebut didasarkan pada ukuran dan kuantitas kedelai hasil panen. Pola distribusi kedelai dilakukan dengan cara mengirimkannya menggunakan mobil bak atau truk. Faktor pengiriman kedelai merupakan faktor yang cukup rentan dan sulit sebab kedelai merupakan komoditas yang mudah rusak (high perisable) sehingga pengiriman kedelai perlu menjadi perhatian yang serius. Berdasarkan saluran distribusi, pola aliran rantai pasok kedelai yang dilakukan petani di Kabupaten Grobogan, pertama adalah petani yang menyalurkan hasil panennya kepada petani penangkar benih dan yang kedua adalah petani yang menyalurkan hasil panennya kepada agen dan bandar. Saluran rantai pasok kedelai di Kabupaten Grobogan disajikan pada Gambar 2. 


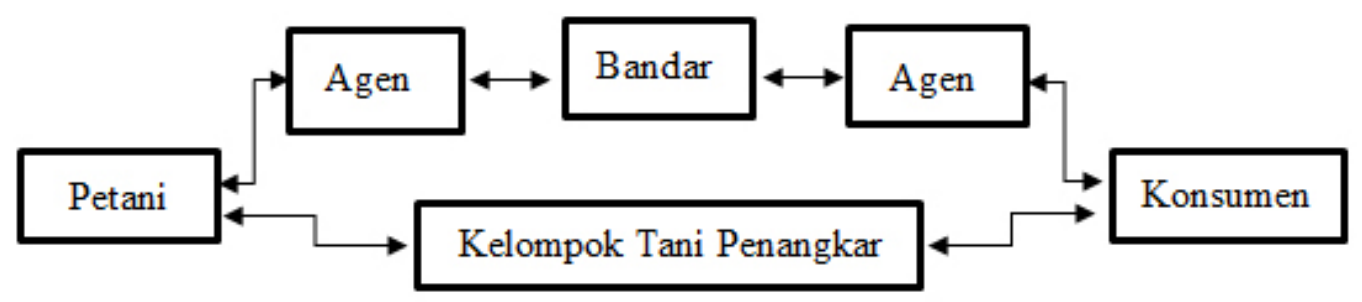

Gambar 2. Saluran rantai pasok kedelai di Kabupaten Grobogan

Aliran rantai pasok kedelai juga didasarkan pada akan dijadikan apa kedelai hasil panen petani tersebut, benih kedelai atau kedelai konsumsi. Berikut merupakan perincian pola aliran rantai pasok kedelai di Kabupaten Grobogan, terdiri dari :

1) Pola Aliran Rantai Pasok Kedelai 1

Petani $\rightarrow$ Kelompok Tani Penangkar $\rightarrow$ Toko Benih $\rightarrow$ Petani

2) Pola Aliran Rantai Pasok Kedelai 2

Petani $\rightarrow$ Bandar $\rightarrow$ Petani

3) Pola Aliran Rantai Pasok Kedelai 3

Petani $\rightarrow$ Bandar $\rightarrow$ Agen $\rightarrow$ Petani

4) Pola Aliran Rantai Pasok Kedelai 4

Petani $\rightarrow$ Agen $\rightarrow$ Bandar $\rightarrow$ Agen $\rightarrow$ Petani

5) Pola Aliran Rantai Pasok Kedelai 5

Petani $\rightarrow$ Agen $\rightarrow$ Bandar $\rightarrow$ Petani

6) Pola Aliran Rantai Pasok Kedelai 6

Petani $\rightarrow$ Kelompok Tani Penangkar $\rightarrow$ Petani

Produk kedelai berupa benih mendominasi hamper 90 persen pangsa pasar dalam aliran rantai pasok kedelai di Kabupaten Grobogan. Hal ini dikarenakan permintaan kedelai dalam bentuk benih lebih mendominasi dibandingkan kedelai konsumsi karena tingginya kebutuhan benih kedelai dari Grobogan yang sudah dikenal dengan kualitasny. Pola pemasaran kedelai pada umumnya petani kedelai menjual seluruh hasil panennya kepada petani penangkar atau bandar baik melalui agen maupun langsung. Baik petani penangkar, bandar maupun agen lebih banyak memasarkan benih kedelai tersebut ke luar Kabupaten Grobogan.

\section{Aspek Risiko}

Menurut Zsidisin dan Ritchie (2004), risiko manajemen rantai pasok berkaitan dengan kegagalan pemasok dalam memasok barang sehingga permintaan konsumen tidak terpenuhi. Risiko yang diterima oleh setiap anggota rantai pasok kedelai berbeda satu sama lainnya. Risiko yang diterima petani lebih disebabkan karena kondisi alam dan instabilitas harga. Sementara itu, risiko yang diterima bandar dan petani penangkar yaitu tidak adanya stok yang diterima karena gagal panen sehingga stok berkurang. Risiko yang dihadapi agen sama dengan resiko yang dihadapi oleh bandar atau penangkar, yaitu tidak terpenuhinya stok kedelai untuk disalurkan.

\section{Analisis Atribut Metrik Kinerja SCOR}

Tujuan dari penelitian ini adalah mengetahui kinerja rantai pasok kedelai secara umum di Kabupaten Grobogan. Kinerja rantai pasok merupakan tingkat kemampuan rantai pasok tersebut untuk memenuhi kebutuhan konsumen dengan mempertimbangkan indikator kinerja kunci yang sesuai pada waktu dan biaya tertentu (Vorst, 2006). Pengukuran kinerja diartikan sebagai proses kuantifikasi efektivitas dan efisiensi dari sebuah aktivitas (Neely et al. 1995). Pengukuran kinerja rantai pasok kedelai di Kabupaten Grobogan dilakukan dengan melihat indikator metrik kinerja yang didasarkan pada SCOR dan disesuaikan dengan kondisi tata niaga kedelai dari petani sampai konsumen.

Pengambilan data dilakukan melalui wawancara dengan petani di Kecamatan Pulokulon Kabupaten Grobogan. Pengukuran kinerja dilakukan selama empat bulan atau dapat dikatakan dalam satu periode masa tanam kedelai. Pengukuran kinerja dilakukan pada petani anggota kelompok tani di Kecamatan Pulokulon Kabupaten Grobogan. Dari 10 orang petani yang diambil sampelnya, tujuh petani merupakan petani mitra penangkar sedangkan tiga orang petani lainnya mitra bandar. Menurut Setiawan et al. (2011) rancangan metrik kinerja meliputi kinerja pengiriman, kesesuaian dengan standar mutu, pemenuhan pesanan, leadtime pemenuhan pesanan, siklus waktu pemenuhan pesanan, fleksibilitas pesanan, biaya SCM, cash-tocash cycle time dan persediaan harian, dengan hasil perhitungan disajikan pada Tabel 5. 
Tabel 5. Penilaian metrik kinerja rantai pasok kedelai tahun 2014-2016

\begin{tabular}{lccc}
\hline \multirow{2}{*}{ Metrik kinerja } & \multicolumn{3}{c}{ Tahun } \\
\cline { 2 - 4 } & 2014 & 2015 & 2016 \\
\hline Kinerja pengiriman (\%) & 100 & 100 & 100 \\
Pemenuhan pesanan (\%) & 100 & 100 & 100 \\
Kesesuaian dengan standard (\%) & 98,7 & 99,21 & 99,64 \\
Waktu tunggu pemenuhan pesanan (hari) & 3 & 3 & 3 \\
Siklus pemenuhan pesanan (hari) & 20 & 20 & 20 \\
Fleksibilitas rantai pasokan (hari) & 120 & 120 & 120 \\
Biaya total SCM (Rp/kg) & 11.200 & 11.400 & 11.700 \\
Siklus cash to cash (hari) & 1 & 1 & 1 \\
Persediaan harian (hari) & 3 & 3 & 3 \\
\hline
\end{tabular}

Berdasarkan penilaian atribut kinerja rantai pasok pada Tabel 5 bahwa kinerja kelompok tani dalam pengiriman pesanan ke pelanggan cukup sempurna dengan $100 \%$ pemenuhan sesuai dengan harapan pelanggan. Metrik pemenuhan pesanan mengalami kestabilan di angka 100\%. Bila terdapat ketidaksesuaian pada realibilitas pemenuhan pesanan diakibatkan oleh adanya ketidaksesuaian pada saat proses pemesanan berlangsung, biasanya adanya keterlambatan distribusi yang disebabkan pesanan mendadak dari konsumen, di mana petani belum siap memasok kedelai, namun di Kabupaten Grobogan kondisi tersebut jarang terjadi karena ketersediaan stok melimpah. Kesesuaian produk dengan standar kualifikasi juga mengalami peningkatan dari $98,7 \%$ pada tahun 2014, pada tahun 2015 sebesar 99,21\% pada tahun 2016 sebesar 99,64\%. Dari hasil perhitungan tersebut, indikator utama yang menjadi fokus perhatian bagi perbaikan kinerja petani yaitu metrik kinerja pemenuhan pesanan dan kesesuaian dengan standar mutu. Hal ini harus diantisipasi dengan penerapan pengawasan mutu produk di antaranya penggunaan bibit berkualitas, budi daya yang baik, aplikasi pemupukan yang tepat serta penanganan panen dan pascapanen yang benar.

Pengukuran atribut kinerja ke dua ditinjau berdasarkan matrik responsivitas, menggunakan siklus pemenuhan sempurna. Pemenuhan besarnya nilai siklus pemenuhan pesanan sempurna diukur dari rataan jumlah hari yang dibutuhkan perusahaan dalam pengiriman produk ke konsumen, mulai dari konsumen memesan barang hingga barang sampai di tangan konsumen. Kinerja responsivitas untuk metrik waktu tunggu pemenuhan pesanan memerlukan waktu tiga hari, kapan pun petani menerima kabar pemesanan maka bila stok cukup tersedia, pada hari yang sama akan dikirim untuk pemesan di sekitar Kabupaten Grobogan dan menerima pengambilan produk untuk konsumen di luar Kabupaten Grobogan. Siklus pemenuhan pesanan membutuhkan waktu 20 hari. Kondisi ini disesuaikan dengan proses mulai dari pengangkutan produk di lapang, tahap sortasi dan pascapanen, sertifikasi benih di BPSB, pengemasan hingga pendistribusian ke konsumen.

Pengukuran atribut kinerja selanjutnya adalah fleksibilitas rantai pasok yang diukur berdasarkan kemampuan kelompok tani memenuhi permintaan tambahan dari pembeli yang terjadi secara mendadak atau tiba-tiba. Bila mana kelompok tani mampu memenuhi tambahan pesanan tersebut dalam waktu yang lebih singkat, dapat dikatakan memiliki fleksibilitas yang baik. Fleksibilitas rantai pasok adalah keuletan rantai pasok perusahaan dan kemampuan untuk beradaptasinya terhadap perubahan pasar untuk memelihara keuntungan kompetitif rantai pasoknya (Supply Chain Council, 2006). Nilai fleksibiltas membutuhkan waktu 120 hari dikarenakan waktu tanam yang dibutuhkan untuk produksi kedelai yaitu selama 90 hari serta penanganan pascapanen, proses sortir dan produksi benih serta proses sertifikasi benih di BPSB selama kurang lebih 30 hari. Total waktu yang dibutuhkan hingga menjadi benih kedelai siap jual ratarata selama 120 hari.

Biaya rantai pasok diperoleh dengan menggunaan rumus harga penjualan pokok (HPP). Biaya rantai pasok pada tahun 2014 sebesar Rp11.200 pada tahun 2015 sebesar Rp11.400 dan pada tahun 2016 dan Rp11.600. Untuk persediaan dana cash dari konsumen, membutuhkan waktu hanya sehari sejak dipesan. Persediaan harian hanya dilakukan maksimal tiga bulan karena bila terlalu lama akan menurunkan kualitas dan mutu benih 
kedelai. Sesuai dengan pendapat Rusell dan Taylor (2014) menyatakan sistem inventori menyebabkan barang-barang berjalan melalui alur distribusi hingga sampai ke tangan konsumen ketika tahapan-tahapan prosesnya tidak saling sinkron.

Siklus cash to cash menghitung kecepatan rantai pasokan mengubah sediaan menjadi uang. Semakin pendek waktu yang dibutuhkan maka semakin bagus kinerja aset rantai pasok. Hasil pengukuran menunjukkan bahwa penyediaan benih kedelai memiliki nilai siklus cash to cash yang cukup baik karena memiliki nilai sehari, di mana nilai tersebut adalah penyelesaian terbaik. Guna meningkatkan kecepatan siklus cash to cash sehingga mencapai kriteria terbaik, maka kelompok tani perlu menjaga hubungan kemitraan dengan pemasok dan konsumen.

\section{Implikasi Manajerial}

Implikasi manajerial yang bisa diterapkan pada rantai pasok kedelai dimulai dari petani yang mensuplai kedelai, konsumen benih dan konsumen kedelai konsumsi. Hubungan petani sebagai pemasok kedelai bagi kelompok tani penangkar harus dijalin dengan baik, begitu juga kualitas kedelai agar 100\% layak dijual ke konsumen benih dengan harga yang cukup tinggi agar dapat meningkatkan pendapatan petani. Penerapan bagi konsumen benih yaitu lebih memfokuskan dalam penyediaan alat transportasi yang lebih banyak sebagai sarana pengangkutan benih kedelai untuk menjamin kualitas dan kuantitas produk. Selain itu, bila terdapat masalah mengenai produk, kelompok tani penangkar harus lebih terbuka menjaga komunikasi kepada petani agar bisa mencapai kesepakatan bersama. Hal ini dilakukan untuk meminimalisasi keluhan pelanggan terkait kualitas dan kuantitas produk. Menurut Budiyanto (2011), pengembangan agroindustri memerlukan perangkat kelembagaan rantai pasok yang memadai, sehingga terdapat sebuah jembatan bisnis bagi kepentingan petani dan industri serta menciptakan struktur industri yang ideal. Hasil identifikasi rantai pasok kedelai di Kabupaten Grobogan menunjukkan terbentuknya kelembagaan antar pelaku rantai pasok.

Hasil identifikasi rantai pasok kedelai di Kabupaten Grobogan menunjukkan bahwa struktur rantai pasok kedelai di Kabupaten Grobogan melibatkan peran bandar, agen dan perusahaan benih di dalamnya untuk memasarkan kedelai ke konsumen. Bandar dan agen bertindak sebagai distributor kedelai, bandar dapat mendistribusikan kedelai ke mana saja baik itu ke agen, ke pemerintah, ke pasar maupun ke unit pengolahan kedelai. Selain sebagai distributor, bandar juga sebagai driver yang membawahi pelaku rantai pasok untuk memproduksi kedelai sesuai dengan kebutuhan dan permintaan pasar, serta mengembangkan aktivitasaktivitas yang memungkinkan untuk mendapatkan nilai tambah pada tingkat petani. Keberadaan konsumen benih dinilai cukup efektif dalam rangka memangkas rantai pasok di Kabupaten Grobogan, karena petani dapat langsung memiliki akses langsung terhadap konsumen.

\section{KESIMPULAN DAN SARAN}

\section{Kesimpulan}

Struktur rantai pasok kedelai di Kabupaten Grobogan terdiri dari petani, kelompok tani penangkar, agen, bandar dan konsumen. Konsumen, yaitu pihak swasta dan pemerintah baik skala kecil maupun besar. Hasil identifikasi rantai pasok kedelai di Kabupaten Grobogan menunjukkan terbentuknya kelembagaan antar pelaku sehingga dapat menguatkan struktur rantai pasok. Sebagian besar hubungan proses bisnis di antara mereka tidak memiliki kesepakatan kontraktual tertulis, cukup mengandalkan rasa saling percaya dan saling membutuhkan. Namun, yang memiliki peranan besar sebagai penentu harga adalah bandar dan kelompok tani penangkar, karena keduanya yang dapat menetukan keputusan proses pembelian kedelai dari petani.

Secara umum kinerja rantai pasok kedelai di Kabupaten Grobogan dikatakan cukup baik, hal ini dapat dilihat dari pengiriman pesanan ke pelanggan dan pemenuhan pesanan yang sempurna, kesesuaian produk dengan standar kualifikasi yang terus meningkat, waktu tunggu pemenuhan pesanan yang tidak terlalu lama, siklus pemenuhan pesanan juga dapat disesuaikan dengan ketersediaan stok, fleksibiitas rantai pasokan masih dapat doptimalkan bila terdapat pesanan mendadak dan biaya rantai pasok yang dapat tertutupi penjualan kedelai. 


\section{Saran}

Petani mitra sebagai pemasok kedelai bagi kelompok tani harus dijalin dengan baik, juga kualitas kedelai agar 100\% layak di jual ke konsumen benih dengan harga yang cukup tinggi dengan tujuan untuk meningkatkan pendapatan petani. Penerapan bagi konsumen yaitu lebih memfokuskan dalam penyediaan alat transportasi yang lebih layak sebagai sarana pengangkutan benih kedelai untuk menjamin kualitas dan kuantitas produk mulai lapangan (petani mitra) hingga proses pengolahan (processing) di kelompok. Kelompok tani pun harus lebih terbuka untuk menjaga komunikasi dua arah agar bisa mencapai kesepakatan bersama (win-win solution) bila ada permasalahan yang menyangkut kepentingan kedua belah pihak.

\section{DAFTAR PUSTAKA}

Astuti R, Arkeman Y, Marimin, Poerwanto R. 2010. Kebutuhan dan struktur kelembagaan rantai pasok buah manggis. Jurnal Manajemen Bisnis 3(1):99-115.

Atman. 2009. Strategi peningkatan produksi kedelai di Indonesia. Jurnal Ilmiah Tambua 8:39-45.

Budiyanto MAK. 2011. Optimasi pengembangan kelembagaan industri pangan organik di Jawa Timur. Jurnal Teknik Industri 12(2):169-176. https://doi.org/10.22219/JTIUMM.Vol12. No2.169-176.

Chopra S, Meindl P. 2007. Supply Chain Management: Strategy, Planning and Operation. New York: Pearson Prentice Hall.

Fizzanty T, Aminullah E. 2010. Skenario Penyediaan Kedelai di Indonesia: Sebuah Analisis Kebijakan. Jakarta: PAPPI-PTEK LIPI.

Isnia M, Hariyati Y, Kusmiati A. 2017. Analisis manajemen rantai pasok susu sapi perah pada koperasi peternak galur murni di Kecamatan Sumberwaru Kabupaten Jember. Jurnal Sosisal Ekonomi Pertanian 10(1):65-76. https://doi. org/10.19184/jsep.v10i1.4895.

Isnowati S. 2014. Faktor yang mempengaruhi produksi kedelai di Desa Kebonagung Kecamatan Tegowanu Kabupaten Grobogan. Jurnal Sosial Ekonomi Pertanian dan Agribisnis (SEPA)10(2):177-185.

Iriani E, Handoyo J. 2011. Perbanyakan Benih Kedelai Varietas Grobogan di Tingkat Petani Dalam Rangka Mendukung Ketersediaan Benih
Kedelai di Jawa Tengah. Dalam: Prosiding Semiloka Nasional Dukungan Agro-Inovasi untuk Pemberdayaan Petani. Semarang, 14 Juli 2011. Semarang: UNDIP.

Kementan. 2015. Roadmap Peningkatan Produksi Kedelai. Jakarta: Direktorat Jenderal Tanaman Pangan.

Marimin, Nurul M. 2010. Aplikasi Teknik Pengambilan Keputusan dalam Manajemen Rantai Pasok. Bogor: IPB Press.

Martius E. 2008. Kemitraan agribisnis untuk memberdayakan ekonomi rakyat. Jurnal Agribisnis Kerakyatan 1(1):1-11.

Nasution R. 2003. Teknik Sampling. Medan: Digital Library Universitas Sumatera Utara.

Neely A, Gregory M, Platts K. 1995. Performance measurement system design: a literature review and research agenda. International Journal of Operations and Production Management 15(4):80-116. https://doi. org/10.1108/01443579510083622.

Nuhung IA. 2013. Kedelai dan politik pangan. Jurnal Forum Penelitian Agro Ekonomi 31(2):132-135. https://doi.org/10.21082/fae.v31n2.2013.123135.

Russel RS, Taylor BW. 2014. Operations and Supply Chain Management. 8th Ed. New Jersey: John Wiley and Sons Singapore Pte, Ltd.

Ruswanti E. 2011. Pengaruh pemasaran kemitraan terhadap keunggulan bersaing. UEU-JournalPeran Perilaku 2(1):17-24.

Saptana, Ashari. 2007. Pembangunan pertanian berkelanjutan melalui kemitraan usaha. Jurnal Litbang Pertanian 26(4):123-130.

Setiawan A, Arkeman Y, Marimin, Udin F. 2010. Integrasi model SCOR dan fuzzy AHP untuk perancangan metrik pengukuran kinerja rantai pasok sayuran. Jurnal Manajemen dan Organisasi 1(3):148-161.

Setiawan A, Arkeman Y, Marimin, Udin F. 2011. Studi peningkatan kinerja manajemen rantai pasok sayuran dataran tinggi terpilih di Jawa Barat. Jurnal Agritech 31(1):60-70.

Simatupang P, Marwoto, Swastika DKS. 2005. Pengembangan kedelai dan kebijakan penelitian di Indonesia. Dalam: Lokakarya Pengembangan Kedelai di Lahan Sub Optimal. Malang, 26 Juli 2005. Malang: Balitkabi.

Sundram VPK, Ibrahim AR, Govindaraju GJRC. 2011. Supply chain management practices in the electronics industry in Malaysia. Benchmarking: 
An International Journal 18(6):834-855. https:// doi.org/10.1108/14635771111180725.

Vorst, JGAJ Van der. 2006. Performance Measurement in Agrifood Supply Chain Networks: An Overview. Netherlands: Wageningen University.

Zakiah. 2011. Dampak impor terhadap produksi kedelai nasional. Jurnal Agrisep 12(1):1-10.
Zsidisin GA, Ritchie B. 2009. Supply chain risk management-developments, issues and challenges. International Series in Operations Research \& Management Science 124:1-12. https://doi.org/10.1007/978-0-387-79934-6_1. 